\title{
Effect of a Motor Physical Program on Psychologically activty Coordination and the Sense of Loneliness and future anxiety in Children Deprived of Family Care "Dr/ sawsan hosny mahmod
}

\section{Research problem and importance:}

Physical education with its different activities is a rich field where the child satisfies his needs to communicate with other children leading to the development the child selfconfidence and to help him understand human relationships very well, hence, the child can understand his personality and his social and emotional adaptation and consequently, the child will grow up balanced and achieve integrated education for children. Child participation in group physical activities characterized by the spirit of cooperation helps develop the child's sense of responsibility, the spirit of the group, be away from isolation, shame, keep and understand the rights of the mate enrich the spirit of competition, support selfesteem and enjoy experiences of the success the child meets during the performance that considered a co-factor in modifying negative trends to positive ones towards himself and others (23:36). Also the child participation in motor activities develops the spirit of competition and supports the positive self-concept (2:96).

The death of parents, the imprisonment of one of them etc. leads to loss of the entity responsible for their raising and guidance i.e. the family. In this case the state fulfills its duty toward those children by placing them in special foundations to take care of them, however, those children may suffer from some psychological and behavioral problems due to the lack of the family life leading to their facing non-sufficient consideration particularly in respect of the psychological aspect causing negative effects on this category that can suffer from psychological disorders in their future life.

Results of some studies showed that circumstances of raising children in sheltering

Asst. Prof. Dept. of Curricula and Methods of Teaching Physical Education, Faculty of Physical Education for Girls, Helwan University Assiut Journal For Sport Science Arts 
foundations constituted one of the reasons of the psychological loneliness phenomenon among those children leaving negative psychological consequences like the child's sense of disability to live in coordination with himself and persons around him leading to reduce the level of the efficiency of his behavior and in turn his ability to produce is lowered generally (1992)(18) and accordingly his image of selfesteem is affected as the child views the self as the essence of personality and the selfconcept is the corner stone in it (9). Experts expect that selfconcept develops in children through their interaction with their peers in school and those around. Neglecting the child and lack of attention leads to feelings within his depths representing one of the most important reasons that make the child form a negative selfconcept.

Late childhood of (9 to 12) years is considered the most important age in man's life where his personality starts to be built and formed in all mental, cognitive, social, emotional and psychological aspects and etc.
The researcher thinks that it is important to consider activity programs given to children in that age due to its importance for healthy physical and motor growth and to meet the child's needs for activity and performing physical activities characterized by activity and motion.

Also social conditions facing children deprived of family care may have an effect on the psychological aspects of the child due to his feeling of the deprivation of kindness and tenderness of his family and peers in school or those around him. Neglecting the child and feelings originated in his depths is one of the most important reasons leading to form a negative concept toward himself.

\section{Fouad Abu Hatab} (2001) indicated that feeling of security threat and deprivation of sympathy and fear may negatively affect the child growth and his psychological and social coordination.

Loneliness related to children deprived of family care is considered as a social and psychological problem blocking this category to achieve their goals and 
psychological and life needs, in addition, the child may have negative concept toward his self and he feels that he is less than the others due to his deprivation of sympathy and tenderness for the loss of his parents and his sense of fear may affect negatively on the child's growth and his personal and social coordination.

The researcher viewed that it was possible through physical activities to improve the individual's sense of self and his view to his self and what reflected to his coordination with his self and the society where he lives positively. Luschen and Sag indicated that improvement of the child's personality as a psychological aspect and important need could get its way through activities of games and sport within rated physical programs enabling the child to grow socially and to acquire several personal and acceptable traits (25: $98 \& 99)$.

The researcher noticed that mini games could be considered as an educational and effective means in the field of gratification of the child's needs, his self-achievement and verification of his existence within the group with whom he works and that gratifies his needs to the sense of appreciation from others and improvement his social interaction (7-294).

Thus the researcher decided to think how to help children of (9 to 12) years, deprived of family care through establishing a program of group competitive and cooperative mini games and knowing the effect of such program on the sense of loneliness and psychologically personal and social coordination.

\section{Research objective}

The aim of the current research was to establish a motor activity program and to identify its effect on psychological adjustment (personal and social) loneliness and future anxiety among children deprived of family care.

\section{Research hypotheses:}

1- There are statistically significance differences between pre and post test of psychological adjustment towards post test mean score.

2- There are statistically significance differences between pre and post test of loneliness towards pre test mean score. 
3- There are statistically significance differences between pre and post test of future anxiety towards pre test mean score.

\section{Research procedures:}

\section{Method:}

The researcher used the experimental method of one group by using pre and postmeasurements to suite the nature of the research.

\section{Research people:}

The children in the association that is a sheltering association taking care of orphan children deprived of family care and teaching them in all educational stages, were selected intentionally. They were ( 9 to 12) years of age and comprised (37) children representing all children in this age and staying in the association.

\section{Sample:}

The main research sample was selected randomly from the research society and included (22) children and the remained (15) children were used for the pilot studies to carry out scientific coefficients for stability and validity tests. The researcher selected this age group (9 to 12) years representing the late childhood

\section{Table (1)}

Arithmetic mean, standard deviation and skewness coefficients for the research sample in variables under investigation $(n=22)$ and from the point of view of psychologists, such age group is considered the best age to improve social skills, to implant ethical values and principles and to develop psychological characteristics meaning that it is the social naturalization stage (2:66). Also children in this age prefer games in general and competitive adventuring and self verification games in particular. Meanwhile, children in this age are able to play with the group and they try to achieve its relevant goal.

The researcher decided to select My Brothers Association to apply the research, and because the number of children in this age (9 to 12) years are available, and there are a big area in the association that help apply the current study easily and freely. The researcher conducted the harmony in variables of age, height, weight, psychological variables such as psychological loneliness and personal and social coordination as stated in Table (1).

$$
\text { Assiut Journal For Sport Science Arts }
$$




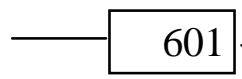

\begin{tabular}{|c|c|c|c|c|c|c|}
\hline \multicolumn{2}{|c|}{ Variables } & $\begin{array}{c}\text { Measuring } \\
\text { unit }\end{array}$ & $\mathbf{M}$ & S.D & Median & Skewness \\
\hline \multirow{3}{*}{$\begin{array}{c}\text { Anthropometric } \\
\text { variables }\end{array}$} & Age & Year & 11.65 & 0.84 & 11 & 2.32 \\
\hline & Height & $\mathrm{Cm}$ & 135.75 & 5.41 & 135 & 0.416 \\
\hline & Weight & $\mathrm{Kg}$ & 32.85 & 5.62 & 32 & 0.454 \\
\hline \multirow{5}{*}{$\begin{array}{c}\text { Test of } \\
\text { psychological } \\
\text { loneliness }\end{array}$} & $\begin{array}{c}\text { Relationships } \\
\text { with friendship, } \\
\text { affection and } \\
\text { love and to what } \\
\text { extent lacking } \\
\text { them } \\
\end{array}$ & Score & 18.85 & 2.76 & 18 & 0.924 \\
\hline & $\begin{array}{c}\text { Sense of } \\
\text { loneliness and } \\
\text { social avoidance }\end{array}$ & Score & 17.66 & 3.11 & 17 & 0.637 \\
\hline & $\begin{array}{l}\text { Social Score } \\
\text { skills and to } \\
\text { what extent is } \\
\text { lacking }\end{array}$ & Score & 17.66 & 2.69 & 17 & 0.716 \\
\hline & $\begin{array}{l}\text { Fear and lack } \\
\text { of confidence }\end{array}$ & Score & 17.28 & 2.4 & 17 & 0.286 \\
\hline & Total of tests & Score & 72.65 & 9.140 & 72 & 0.184 \\
\hline \multirow{3}{*}{$\begin{array}{c}\text { Test of } \\
\text { psychological } \\
\text { coordination }\end{array}$} & $\begin{array}{c}\text { Personal } \\
\text { coordination }\end{array}$ & Score & 27,82 & 4.11 & 27 & 0.599 \\
\hline & $\begin{array}{c}\text { Social } \\
\text { coordination }\end{array}$ & Score & 30.36 & 2.86 & 30 & 0.378 \\
\hline & $\begin{array}{l}\text { Psychological } \\
\text { coordination }\end{array}$ & Score & 57.18 & 5.76 & 58 & 0.094 \\
\hline \multirow{6}{*}{ future anxiety } & Problems of life & Score & 13.166 & 1.205 & 13 & $0.215-$ \\
\hline & $\begin{array}{c}\text { Concerned } \\
\text { health and death }\end{array}$ & Score & 12.266 & 1.48 & 13 & 0.383 \\
\hline & $\begin{array}{l}\text { Mental } \\
\text { anxiety }\end{array}$ & Score & 22.700 & 2.548 & 23 & $1.891-$ \\
\hline & $\begin{array}{l}\text { Despair of } \\
\text { the future }\end{array}$ & Score & 16.733 & 1.460 & 16.500 & 0.926 \\
\hline & $\begin{array}{l}\text { Anxiety of } \\
\text { future }\end{array}$ & Score & 14.666 & 1.917 & 14.500 & 0.795 \\
\hline & total & & 80.566 & 4.889 & 80.500 & $0.086=$ \\
\hline \multicolumn{3}{|c|}{$\begin{array}{l}\text { Data in Table (1) illustrate that } \\
\text { skewness coefficients range } \\
\text { between }( \pm 3) \text {, meaning that the } \\
\text { research sample was } \\
\text { harmonized in such variables. } \\
\text { Research tools: } \\
\text { The researcher used the } \\
\text { following tools: }\end{array}$} & \multicolumn{4}{|c|}{$\begin{array}{l}\text { 2- } \quad \text { Scale loneliness. } \\
\text { 3- The training program } \\
\text { prepared by the researcher. } \\
\text { The researcher conducted a } \\
\text { pilot study on purpose to find } \\
\text { out scientific coefficients of }\end{array}$} \\
\hline
\end{tabular}


validity and stability of personal tests, and the sense of psychological loneliness for the pilot research sample of (15) children from the research society but out of the main research sample in the period from Sunday, 2/10/2011 to Monday, 9/10/2011.

1- Children personality test. It was prepared by Attia Hana cited from California's children test of (9 to 12) years. Such test has been prepared by Thorpe, Clark and Tigez and measures the child psychological coordination through the following two main parts:

a. Personal coordination.

b. Social coordination.

2- The scale of the sense of loneliness. After reviewing previous researches and studies introduced loneliness, the researcher concluded that the scale of loneliness prepared by Amani Abdel Maksoud $_{(1)}$ and it has been designed to be applied to children in sheltering institutes in age of (9 to 12) years. The scale consisted of (48) statements distributed to four main axes as follows:

1- Friendship, affection and love relationships and to what extent they are lacking (12).
2- The sense of isolation and social avoidance.

3- Social skills and the range of lacking them.

4- Fear and lack of confidence.

The researcher used the validity of differentiation to calculate the validity of the scale of the sense of psychological loneliness by applying the scale to the pilot research group of (15) children as a non-distinct group and to (15) children from Pyramids Language School of (9 to 12) years as a distinct group. To calculate the stability of the scale, the researcher used the method of application and reapplication with (10) days interval.

The

researcher conducted the validity and stability for psychologically personal and social coordination tests and the test of the sense of psychological loneliness and future anxiety from $4 / 10 / 2015$ to $9 / 10 / 2015$.

3 - The suggested program: The aim of the suggested motor activity program was to have the child to participate in group activities and to motivate him towards the group work and social participation including accepting others, 
interacting with them positively and cooperatively with confidence, following healthy social behavior and feeling responsibility and the spirit of the group and being away from introversion through participation of the child in physical activities characterized by adventure and risk.

The researcher viewed that the abovementioned facts could have an effect on the psychological growth and selfconcept through making use of natural children love and will of motion and play through a set of varied team games that match features of the age of the research sample to establish chances to act in an atmosphere of pleasure, entertainment and competition. Also child participation in group activities are characterized by the spirit of cooperation and participation helps grow the child's sense of responsibility and the group spirit away from shyness, introversion and understanding the rights of the other.

Osama Rateb (3) thought that child participation in motor activity led to improve the spirit of competition and to support positive self-concept in the child. Galiho (23:36) thought that the educational atmosphere provided by motor activities accepted and appreciated by peers and friends as well as experiences of success, the child's meeting during the performance constituted a co-factor in changing negative trends to positive ones toward the self and the others.

Fundamentals of building the program and its content:

. Through reviewing scientific references related to the research topic, the program was established and presented to experts to pilot their opinions in the suggested program constituents and the final form of the program was concluded; provided that the program should achieve its objective matching the age of the research sample and characterized with excitement, variation and work in an atmosphere of enjoyment, pleasure and competition.

- The program consisted of a set of competitions and games to improve the spirit of competition and excitement, to enable the child to acquire his self-confidence, to verify his ego, to increase motivation and to participate in the program activities and games in the content of the program should motivate the spirit of the group working, positive participation 
and cooperation and adherence to healthy physical behavior and the use of moral incentives to encourage children.

The researcher carried out all exercises of the program activity.

Tools used in the program:

Balls, ropes, sticks, rubber lopes, grain sacs, boxes, balloons, mats, Swedish benches, funnels and a cassette player for the assistance of rhythm.

\section{Program content:}

In the light of achieving the objective of the research, the researcher considered that the program should include the following:

- Popular games containing a set of mini games that known and simple tools in the environment used to contribute to meet the child's needs regularly and through which the child learns how to commit to roles of such games and to provide safety and easiness to his peer to treat with the play situations quickly without complication.

Cooperative games that implant in children the importance of treating and cooperating with peers, participating positively, feeling with the team spirit, seeking and making effort to achieve the objective through group and double games with and without tools.

- Competitive games using tools such as balls, rubber lobes, robes and sticks and games without tools to develop the spirit of fair competition and to verify the ego and to learn how to treat the peer with sports spirit and to express his ego freely in the light of roles of the play.

- The researcher thought that the program should include mini, preliminary and popular games. After establishing the program, it has been presented to experts to pilot their opinions on the program content (Attachment 4) as well as time that the program would last to effect positively on the research variables.

\section{Program time distribution:}

- $\quad$ The program lasted (10) weeks at the rate of (3) units a week i.e. (30) units for the program by (40) min. per unit.

- The researcher formed (15) training units and each one consisted of a set of mini, preliminary and popular games provided that the unit was to be applied and re-applied during the whole program meaning that each game was performed twice during the whole program. 
- Varying the research tools used in the program with varying the objectives of the selected games.

- The program was applied in the period from $11 / 10 / 2015$ to $7 / 1 / 2016$ excluding holidays and Eids.

The single training unit consisted of the following:

a. The Preliminary part (warm up) 5 minutes.

b. The main part 30 minutes distributed to (3) games by (10) min. each.

c. Final part $5 \mathrm{~min}$.

The researcher used musical rhythm and popular songs to inspire vitality.

Application of the research tools:

a. Pilot study:

It was carried out to find out scientific treatments for the scale of loneliness and the test of psychologically personal and social coordination on the pilot research sample of (15) children from the same research people but out of the main research sample.

b. Main study:

- Scales were applied to the research experimental group. They were the scale of the loneliness and test of psychological adjustment, social coordination and future anxiety on Thursday, 6/10/2015.

- Application of the program:

The program suggested by the researcher was applied to the experimental research group in the period from Sunday, 9/10/2015 to Thursday, $29 / 12 / 2015$ by (3) units a week on days of Sunday, Tuesday and Thursday with a total number of (30) units for the program and each unit lasted (40) min. excluding holidays.

\section{Post-measurement:}

It was carried out for the scale of the sense of psychological loneliness and test of the psychologically personal and social coordination on the experimental research sample on Saturday, 14/1/2016.

\section{Presentation and discussion of results:}

\section{Presentation of results:}

a. Presentation of results related to the effect of the suggested program on the measurement of the sense of psychological loneliness.

Table (2) 


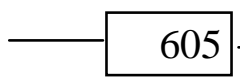

Significance of differences between the pre and postmeasurements on the scale of the sense of psychological loneliness for the research sample $(n=22)$

\begin{tabular}{l|c|c|c|c|c|c}
\hline \hline \multirow{2}{*}{ Scale axes } & \multicolumn{2}{|c|}{$\begin{array}{c}\text { Pre- } \\
\text { measurement }\end{array}$} & \multicolumn{2}{c|}{$\begin{array}{c}\text { Post- } \\
\text { measurement }\end{array}$} & \multirow{2}{*}{ Def. } & $\begin{array}{c}\text { Calculated } \\
\text { t }\end{array}$ \\
\cline { 2 - 6 } & $\mathbf{M}$ & S.D & M & S.D & & \\
\hline $\begin{array}{l}\text { Relationships of } \\
\text { friendship, } \\
\text { affection and } \\
\text { love and to what } \\
\text { extent is lacking } \\
\text { them }\end{array}$ & 22.85 & 2.86 & 17.32 & 0.24 & 5.53 & 8.83 \\
\hline $\begin{array}{l}\text { Sense of } \\
\text { loneliness and } \\
\text { social avoidance }\end{array}$ & 21.74 & 3.11 & 17.70 & 0.54 & 4.04 & 5.87 \\
\hline $\begin{array}{l}\text { Social skills and } \\
\text { to what extent is } \\
\text { lacking }\end{array}$ & 18.69 & 2,66 & 16.12 & 0.56 & 2.53 & 4.22 \\
\hline $\begin{array}{l}\text { Fear and lack of } \\
\text { confidence }\end{array}$ & 19.22 & 2.4 & 16.22 & 0.12 & 3.00 & 5,72 \\
\hline Total of tests & 82.546 & 9.82 & 67.36 & 1.56 & 15.10 & 6.956 \\
\hline \hline
\end{tabular}

Tabulated "t" at $(0.05)$ level $=2.07$

Data in Table (2) illustrate that there are significant differences between the pre and post-measurements

\section{Table (3)}

in favor of the postmeasurement in respect of the sense of psychological loneliness and its axes.

\section{Percentages of the rate of improvement between of the pre and} post-measurements on the scale of psychological loneliness for the research sample $(n=22)$

\begin{tabular}{l|c|c|c|c}
\hline \hline \multicolumn{1}{c|}{ Scale axes } & $\begin{array}{c}\text { Pre- } \\
\text { measurement }\end{array}$ & $\begin{array}{c}\text { Post- } \\
\text { measurement }\end{array}$ & Def. & $\begin{array}{c}\text { Improvement } \\
(\%)\end{array}$ \\
\hline \hline $\begin{array}{l}\text { 1- Relationships } \\
\text { of friendship, affection } \\
\text { and love and to what } \\
\text { extent is lacking them }\end{array}$ & 22.85 & 17.32 & 5.53 & 24.2 \\
\hline $\begin{array}{l}\text { 2- Sense of } \\
\text { loneliness and social } \\
\text { avoidance }\end{array}$ & 21.74 & 17.7 & 4.04 & 18.28 \\
\hline \hline
\end{tabular}

Follow Table (3) 
Percentages of the rate of improvement between of the pre and post-measurements on the scale of psychological loneliness for the research sample $(n=22)$

\begin{tabular}{|c|c|c|c|c|c|c|}
\hline Scale axes & \multicolumn{2}{|c|}{$\begin{array}{c}\text { Pre- } \\
\text { measurement }\end{array}$} & \multicolumn{2}{|c|}{$\begin{array}{c}\text { Post- } \\
\text { measurement }\end{array}$} & Def. & $\begin{array}{c}\text { Improvemen } \\
(\%)\end{array}$ \\
\hline $\begin{array}{l}3-\quad \text { Social skills } \\
\text { and to what extent is } \\
\text { lacking }\end{array}$ & \multicolumn{2}{|c|}{18.65} & \multicolumn{2}{|c|}{16.12} & 2.35 & 13.566 \\
\hline $\begin{array}{l}\text { 4- Fear and } \\
\text { lack of confidence }\end{array}$ & \multicolumn{2}{|c|}{19.22} & \multicolumn{2}{|c|}{16.22} & 3.00 & 15.61 \\
\hline Total of tests & \multicolumn{2}{|c|}{82.46} & \multicolumn{2}{|c|}{67.36} & 15.10 & 18.31 \\
\hline \multicolumn{7}{|c|}{$\begin{array}{l}\text { Data in Table (3) show } \\
\text { that the percentages of } \\
\text { improvement between the pre } \\
\text { and post-measurements range } \\
\text { from } 13.566 \% \text { and } 24.2 \% \text { on } \\
\text { the scale of the sense of }\end{array}$} \\
\hline \multirow[t]{2}{*}{ Scale axes } & \multicolumn{2}{|c|}{$\begin{array}{c}\text { Pre- } \\
\text { measurement }\end{array}$} & \multicolumn{2}{|c|}{$\begin{array}{c}\text { Post- } \\
\text { measurement }\end{array}$} & \multirow[t]{2}{*}{ Def. } & \multirow{2}{*}{$\begin{array}{c}\text { Calculated } \\
\mathbf{t}\end{array}$} \\
\hline & $\mathbf{M}$ & S.D & $\mathbf{M}$ & S.D & & \\
\hline $\begin{array}{l}\text { Personal } \\
\text { coordination }\end{array}$ & 27.82 & 4.11 & 34.25 & 3.72 & 6.43 & 5.315 \\
\hline $\begin{array}{l}\text { Social } \\
\text { coordination }\end{array}$ & 30.36 & 2.86 & 36.42 & 4.11 & 6.06 & 5.55 \\
\hline $\begin{array}{l}\text { Psychological } \\
\text { coordination }\end{array}$ & 58.18 & 5.76 & 70.67 & 6.49 & 12.49 & 6.596 \\
\hline
\end{tabular}

Tabulated "t" at (0.05) level =2.07.

Data in Table (4) indicate that there are significant differences between scores of the pre and postmeasurements in favor of the post-measurement in axes of the test of psychological coordination and the total of the test.

\section{Table (5)}




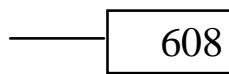

Percentages of rates of improvement in the test of psychological coordination

\begin{tabular}{l|c|c|c|c}
\hline \hline \multicolumn{1}{c|}{ Test axes } & $\begin{array}{c}\text { Pre- } \\
\text { measure } \\
\text { ment }\end{array}$ & $\begin{array}{c}\text { Post- } \\
\text { measurem } \\
\text { ent }\end{array}$ & Def. & $\begin{array}{c}\text { Improv } \\
\text { ement } \\
\text { \% }\end{array}$ \\
\hline \hline Personal coordination & 27.82 & 34.25 & 6.43 & 13.11 \\
\hline Social coordination & 30.63 & 36.42 & 6.06 & 19.96 \\
\hline $\begin{array}{l}\text { Psychological } \\
\text { coordination }\end{array}$ & 58.18 & 70.67 & 12.49 & 21.47 \\
\hline \hline
\end{tabular}

Data in Table (5) present that the percentages of the rates of improvement between the pre and post-measurements in the research sample in the test of psychological coordination are between $19.96 \%$ and $23.11 \%$.

\section{Table (6)}

Significance of differences between the pre and postmeasurements in the test of future anxiety

\begin{tabular}{|c|c|c|c|c|c|c|c|}
\hline & \multirow[t]{2}{*}{ Test axes } & \multicolumn{2}{|c|}{$\begin{array}{c}\text { Pre- } \\
\text { measurement }\end{array}$} & \multicolumn{2}{|c|}{$\begin{array}{c}\text { Post- } \\
\text { * measurement }\end{array}$} & \multirow[t]{2}{*}{ Def. } & \multirow{2}{*}{$\begin{array}{c}\text { Calculat } \\
\text { ed } \mathbf{t}\end{array}$} \\
\hline & & M & S.D & $\mathbf{M}$ & S.D & & \\
\hline \multirow{6}{*}{$\begin{array}{l}\text { future } \\
\text { anxiety }\end{array}$} & $\begin{array}{ll}\begin{array}{l}\text { Problems } \\
\text { the life }\end{array} & \text { of } \\
\end{array}$ & 13.333 & 1.112 & 10.800 & 1.521 & 2.533 & "9.906 \\
\hline & $\begin{array}{l}\text { Concerned } \\
\text { health and death }\end{array}$ & 13.333 & 1.112 & 10.933 & 0.961 & 2.400 & $* 11.225$ \\
\hline & Mental anxiety & 22.800 & 2.651 & 19.333 & 2.636 & 3.466 & * 14.666 \\
\hline & $\begin{array}{l}\text { Despair of the } \\
\text { future }\end{array}$ & 17.000 & 1.511 & 13.933 & 1.437 & 3.066 & *12.357 \\
\hline & $\begin{array}{ll}\begin{array}{l}\text { Enxiety } \\
\text { future }\end{array} \\
\end{array}$ & 14.400 & 1.764 & 11.933 & 1.486 & 2.466 & *8.047 \\
\hline & total & 80,866 & 5.270 & 66.932 & 4.733 & 12.466 & *20.759 \\
\hline
\end{tabular}

Tabulated "t" at (0.05) level $=2.07$.

Data in Table (6) measurements in favor of the indicate that there are post-measurement in axes of significant differences between the test of future anxiety scores of the pre and post-

Table (7) Assiut Journal For Sport Science Arts 


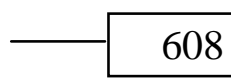

Percentages of rates of improvement in the test of future anxiety

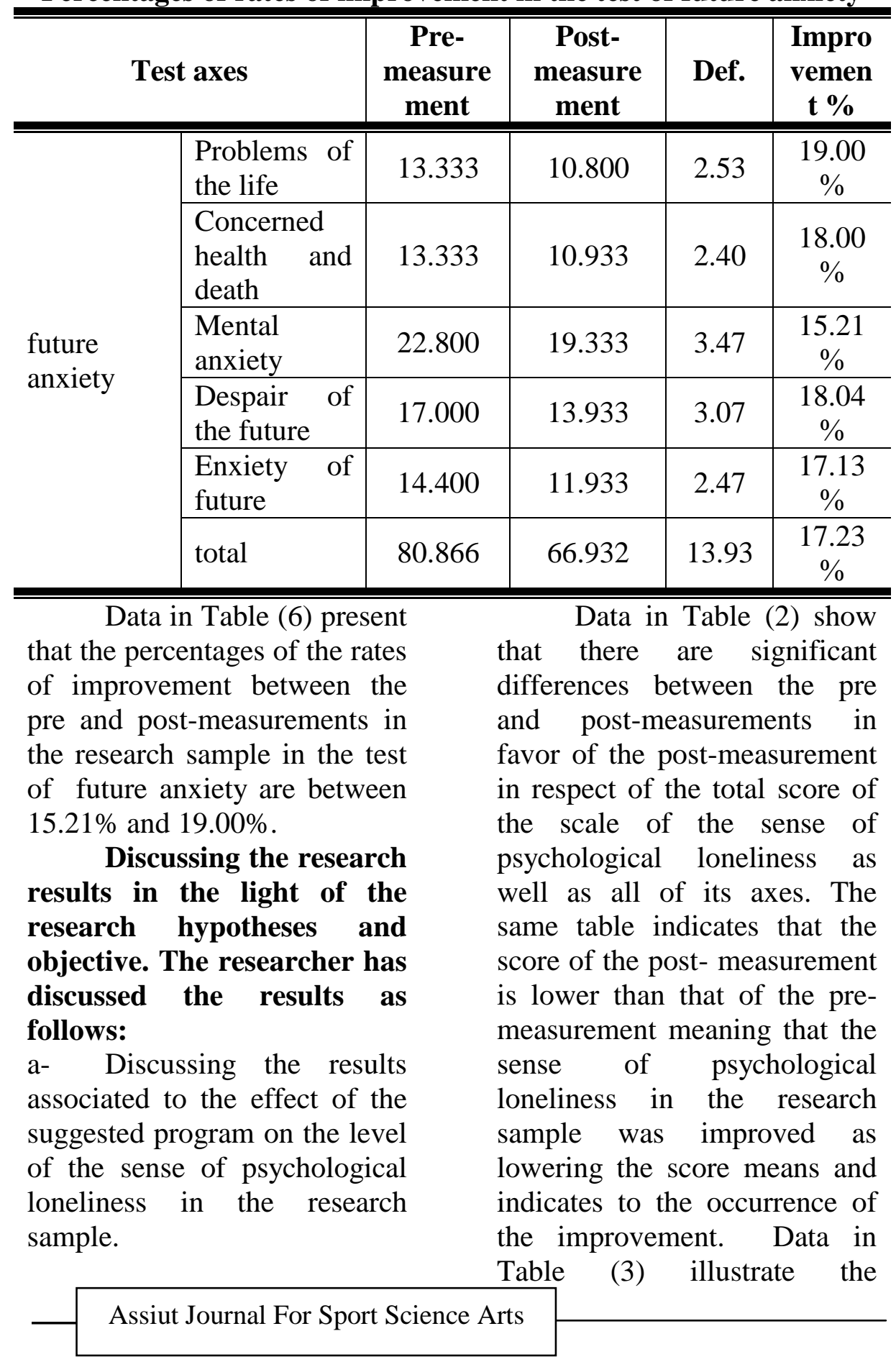


percentages of the rate of improvement in the postmeasurement over the premeasurement in all axes and the total score of the scale ranges from $(13.566 \%$ to $24.2 \%$ ).

The researcher attributed such improvement and the low score of the sense of psychological loneliness in the research sample to the motor program that established and applied by the researcher and that consisted of a set of group motor activities such as mini games, popular games and competitions by using a sort of varied tools viz. balls, rubber lobes, sticks, funnels etc. representing activities loved by children leading to attract the children due to the excitement, variety, sharing performance, group working in group activities launched by the program units and exercises, consequently, the child felt his importance in his group, he was able to treat his peers easily and he was given a chance to form friendships and love and safe relationships as he was dealing with a community he loved and the community liked him as well as friendships replaced to some extent lacking family affection that resulted in reducing the sense of frustration, isolation and fear. The children were given the chance to communicate with the others and to increase their friends and to react with them. Meanwhile, the use of tools and simple sports devices and various formats led to the belonging, cooperation and incorporation among the children in the experimental group that helped improve general relationships and helped children feel of being considered resist shyness and introversion and depend on them, unload their depressed feelings, feel their rights in the society and be in an equity with others that encouraged them to feel self-confidence, to accept his ego and be satisfied.

The researcher thought that the content of the program of activities full of pleasure and enthusiasm that liked by the children helped them bear responsibility, incorporate with the others, release fears and cooperate with peers leading to get away from their isolation, to feel loneliness and introversion and consequently, the child achieved psychological satisfaction and 
reduced the level of the sense of psychological loneliness.

The abovementioned facts approved the $1^{\text {st }}$ hypothesis saying" the suggested physical program has a positive effect on the level of the sense of psychological loneliness in children in depository institutions who deprived from family care and were (9 to 12) years.

b- Discussing the results related to the effect of the suggested program on psychologically personal and social coordination.

Data in Table (4) illustrate that there are significant differences between scores of the pre and postmeasurements in the research sample in psychologically personal and social coordination in favor of the post- measurement indicating that the program suggested by the researcher had a positive effect on such personal variables. The researcher attributed that to the program she has established and applied and that consisted of a sort of games and competitions challenging the children's ability whether by free working or tools motivated the children's enthusiasm and their attraction to such games, acquired them self-confidence, verified their egos and motivated the spirit of competition and challenge. All of these had a positive effect on the child's view, his selfconcept and his treatment with the others and affecting his psychologically personal and social coordination.

The abovementioned facts was confirmed by David Ebelka (1994) who indicated that mini games matched with the age specified for such games affected positively the child understanding his motor abilities and his sense of his ego and value. Such games liberated the child from his tendency toward isolation of the others (9:22). These results were in harmony with those of Iman Al-Nahas (7) and those of

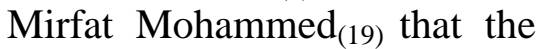
motor activity comprising competitions and natural games and skills motivated children's ego motivation and enthusiasm and acquired selfconfidence, the other's appreciation, favorable behavioral experiences and grew healthy social and personal relationships and consequently, they contribute 
to improve personal coordination.

\section{Data in Table (5) clarify} that the mean of the postmeasurement is higher than that of the post-measurement in the test of psychological coordination in the research sample as the percentage of the rates of variation of the premeasurement over those of the post-measurement are between (19.96 and 23.11) indicating the positive effect of the suggested motor program on psychologically personal and social coordination in children in the research sample. These results agreed (1990) who stated that various motor activity programs and games helped the child grow socially and made him acquire several acceptable personality traits and consequently, the child's psychologically personal and social coordination was increased (3:103), thus, they agreed with those of Kelair Faheem (1998) who stated that the play was an important factor for the child's social coordination and psychological balance as the child acquired new skills and experiences that increased his self-confidence and the expression of his internal emotions (14).
That illustration achieved the $2^{\text {nd }}$ hypothesis saying" the suggested program of group games has a positive effect on the level of psychological coordination in children of $(9$ to 12) years who deprived of family care.

c- Table (6-7) shows that there are statistically significant differences between the pre and post measurement of the experimental and control groups in the future anxiety variable The researcher explains that the program used and its contents of the exercises and movements and various skills and with or without equipments using of music has had the positive effect of increasing the ability to convey feelings and emotions within the limits and capacities of children For any type of sports activities to highlight the outcome of training in the proposed program in a clear way to influence the alleviation of the concern of the future 'Zeinab Sha'ir (2005) noted that future anxiety is one of the types of anxiety that are dangerous to one's life Which represents an unknown fear that results from past and present experiences also makes the one's feels 
unsecure And expect danger and instability. All of this is the cornerstone of safe psychosocial building and minimizing anxiety

\section{Conclusions:}

- Group motor activities positively effect on minimizing the level of the sense of psychological loneliness.

- Group motor activities positively effect on psychologically personal and social coordination.

- Lowering the level of the sense of psychological loneliness in children deprived of family care tends to improve psychologically personal and social coordination.

\section{Recommendations:}

In the light of the conclusions the researcher have achieved, she recommended the following:

a- Considering children deprived of family care by making a program of group physical activities, incorporating them with the others and making effort to join them in different sports activities.

b- Qualified supervision should be provided to take care of such children deprived of family care scientifically to direct them toward the importance of the group activity that helps in cooperation and participation and in turn to assist the child create normal personality coordinated psychologically away from introversion and depression and other traits that are not favored.

\section{References}

\section{Arabic references}

1- Ahmed Ezzat Rageh: Fundamentals of Psychology, Dar Al-Maaref, Cairo, 1990.

2- Osama Kamel Rateb and Ibrahim Abd Rabbou Khalifa: Growth and Emotion in Directing Motor Activity for the Child, Dar Al-Fekr AlArabi, Cairo, 1990.

3- Osama Kamel Rateb: Sport Psychology, Dar Al-Fekr Al-Arabi, Cairo, 2000.

4- Al-Metwali Ibrahim: Study of care techniques provided to children in sheltering institutes and its relationship with the level of anxiety in such children. M.Sc. Thesis (Unpublished), Childhood Studies Institute, Ain Shams University, 1993.

\section{5- Amani Abdel Maksoud} Abdel Wahab: The extent of the effectiveness of a guide program to ease the level of the sense of psychological loneliness in children, 1998. 
6- Amin Anwar Al-Kholi et al: School Physical Education, Class Teacher Handbook, Practical Education Student, Dar Al-Fekr Al-Arabi, $2^{\text {nd }}$ Ed., Cairo, 1990.

7- Iman Al-Nahas: Effect of Effect of a suggested motor activity program on some children physical variables in children of unknown parentage: Ph.D. Thesis (unpublished) Faculty of Physical Education for Girls, Helwan University, 2000.

8- Iman Abdel Aziz Nour AlDin: Effect of a suggested motor innovation program on developing personality in children in primary education in the Sultanate of Oman. Journal of Sciences and Arts of Sport, Faculty of Physical Education for Girls, Helwan University, Vo. (4), No. (3), 1992.

9.

Hamed

Zahran:

Psychological Guide and Instruction, $3^{\text {rd }}$ Ed., Book World, Cairo, 1992.

10- Galilah Moustafa AlSoirky: Effect of the developed curriculum on selfconcept and motor fitness in children in depository institutions. The $1^{\text {st }}$ Scientific Conference on Physical Education and championship, January, 1987.
11- Attia Mahmoud Hana: Children Personality Test. The World House, $1^{\text {st }}$ Ed. The State of Kuwait, 1989.

12- Foad Abo Hatab and Abdel Halim Mahmoud AlSayed: Sociology and Psychology Science. Ministry of Education, Book Sector, 2001.

13- Faten Al-Sayed AboSabah: Behavioral problems in children in institutions and SOS village of (6-12) years. M. Sc. Thesis (unpublished), Children Studies Institute, Ain Shams University, 1999.

\section{4- Klair Faheem:}

Psychological Health of the Primary Child. Al-Hana Bookstore, Cairo, 1998.

15- Lila Labib, Thanaa Emara, Monira Morkos: Mini and Preliminary Games, D. T. 1998.

16- Magda Hassan Al-Gaiar: Effect of a therapeutic dance program on raising efficiency of cardiorespiratory system, reducing the level of anxiety and increasing psychological coordination in orphan children. Journal of Sciences and Arts of Sport, Faculty of Physical Education for Girls, Helwan University, Vol. (18), No. (1), 2003.

17- Madihah Mohammed AlAzabi: A study on some sociopsychological variables related 
to the Stometric status in children in creative institutes. Ph.D. Thesis (unpublished), Faculty of Education, Al-Azhar University, 1980.

18- Mona Kamel Abdulla: Social variables associated with the sense of psychological loneliness in students in the University Hostels, Alexandria University. M.Sc. Thesis (unpublished), Faculty of Education, Alexandria University, 1992.

19- Mirfat Mohammed Ahmed: Effect of obstacle gymnastics on improving some personality traits and their relation to the level of performance in gymnastics for primary school students. Journal of Sciences and Arts of Sport, Faculty of Physical Education for Girls, Helwan University. Vol. (9), No. (1), 2001.

20- Nifeen Mohammed Ali Zahran: Study of psychological loneliness in adolescent orphans of the two sexes and its relation to parents styles of their raising. M.Sc. Thesis (unpublished), Faculty of Education, Ein Shams University, 1994.
21- Barage, Diana and others: Corolates of Loneliness Isolation, Child, Study Journal, V. 24, n. 1992.

22- David E. B. alka: Teaching children Games, Human Kinetics, Publishers inc. COpyright, 1994.

23- David L. Gallahue, John

C. Ozman: Understanding

Motor Development, Third Edition, Brown \& Benchmark Publishers, 1995.

24- Page. R. M., Frey J. and others: Children's Feeling of Loneliness and social Dissatisfaction. Relationship to measurements of physical fitness and Activity Journal of Teaching in Physical Education USA. 1992.

25- Sage Ge. Eds, Luchen. G. Hand Book of social since of sport, steps Pub. Co. Champion, 1981.

26- Waheeda Tabassam, Hamayum: Interlligence and personality Differences among children from orphanages and Intact families, Journal of the Indian Academy of Applied Psychology, Vol 19 (1-2) JanJul 1993. 